\title{
MANGROVE (Bruguiera gymnorrhiza) LEAVES POTENTIAL AS COLOURING AGENT ON COTTON, RAYON, AND SATEEN FABRICS
}

\author{
Cucuk Trisnawati Anggryani, MisbakhulMunir, Dian Sari Maisaroh \\ Marine Science, UIN SunanAmpel Surabaya \\ E-mail :cucuktrisnawati98@gmail.com
}

\begin{abstract}
This study aims to find the value of the fastness test of the natural dye of mangrove leaves (Bruguiera gymnorrhiza). This research was conducted in June-November 2020. This research used descriptive and experimental methods. The samples used were cotton, rayon, and sateen fabrics. The experimental results showed the addition of fixator tunjung $\left(\mathrm{FeSO}_{4}\right)$ capable of binding dye mangrove leaves Bruguiera gymnorrhiza that give color to the fabric fibers. The result of the coloring is brownish yellow. The results of the color fastness value in hot water are influenced by the difference in $\Delta \mathrm{E}$ (colorfastness), cotton fabrics have a range of values between the medium category (5.1-5.94), the medium-large category rayon cloth (5.09-9.06), medium category sateen (3.65-4.35). The results of the color fastness value in cold water are influenced by the difference in $\Delta \mathrm{E}$ (colorfastness), cotton fabrics have a range of values between the small and medium categories (1.96-3.68), rayon fabrics in the small category (2.83-3.9), the small category of sateen fabrics (1.54-2.76).
\end{abstract}

Keywords:Cotton fabric; Rayon fabric; Sateen fabric; fixator; Natural dyes ;Bruguiera gymnorrhiza

\section{INTRODUCTION}

Product quality is the most important aspect in an industry which is based on an assessment of taste and nutritional content, but before that assessment there is a visual assessment such as shape and color that affects the assessment. The addition of dyes is one solution to add artistic value and the selling value of a product [1]. In 1996 the Indonesian Embassy in the Dutch trade sector gave a warning about the dangers of synthetic dyes in all product forms. The use of synthetic dyes in clothing has an impact on triggering skin cancer which is carcinogenic. The chemicals in the synthetic coloring will be discharged to the surrounding environment, so that it will endanger the environment and pollute the environment because it cannot be broken down by nature. The use of extracted natural ingredients is more desirable to try because it has a stable color weight and the coloring material can be used until it runs out. The remainder of the extract waste in the form of solids from the stew can be used as compost. Natural dyes are alternatives that are non-toxic, renewable, easy to degrade and are environmentally friendly [2].

Natural dyes occur naturally in plants. Natural dyes have beautiful colors, are difficult to imitate, decompose easily compared to synthetic dyes. Natural dyes can be produced from bark, twigs, fruit, roots, seeds, flowers and plant sap. Raw materials for the manufacture of natural dyes can be obtained easily because Indonesia has abundant natural resources to provide raw materials sourced from nature. Raw materials from nature are obtained from mangrove trees. Mangrove forests in Indonesia have quite extensive forests, which can be estimated to be about 4,255 million ha spread along the coast and river estuaries [3].
Mangroves in general are coastal plants that have not been widely known for their added value, apart from being used as a beach protector from the impact of sea waves that cause abrasion, it turns out that mangroves are one of the ingredients that can be used as natural dyes in dyeing fabrics because they contain tannins. Tannins are plant pigments with a high molecular weight between 500200,000 and include polyphenol compounds derived from plants with characteristics of being bitter and chewing and able to coagulate proteins [4]. One of the mangroves that contain natural dyes is the mangrove type Bruguiera gymnorrhiza. According to [5], the Bruguiera gymnorrhiza mangrove tree in its leaves contains tannin compounds which can produce brown color for natural dyes in textiles.

Natural dyes are generally only good for dyeing natural fibers such as silk, wool, and cotton. Other synthetic fibers such as polyester and nylon have less appeal to natural dyes so that these materials will be difficult to dye with natural dyes, besides that polyester fabrics also do not have the absorption of natural dyes, so they are not easy in the coloring process [6]. Research on Bruguiera gymnorrhiza mangrove leaves as a natural dye in textiles is available, namely in the research of batik cloth [7], which states that the mangrove plant (Bruguiera gymnorrhiza) has been used by the community to use natural dyes for batik cloth by utilizing petals and fruit skin from the mangrove plant (Bruguiera gymnorrhiza).

This description is the background for conducting this research because the differences in the raw materials used can affect the color results obtained from dyeing natural colors with fabric materials. Each fabric material has different fiber properties and structures, in order to 
produce different color variations in the extraction of mangrove mangrove leaves (Bruguiera gymnorrhiza) it is necessary to use 3 different types of textile materials, namely cotton from cellulose, rayon from semi-cellulose, and sateen from polyester material. Fabrics made from polyester have less affinity for natural dyes because natural dyes do not have amino and carboxyl groups, as a result the resulting color becomes faded. Therefore, before dyeing, the fabric is dipped in a fixator or mordant substance.

\section{RESEARCH METHODS \\ Preparation}

The cloth is washed using distilled water, drained for 24 hours, cut into $15 \times 15 \mathrm{~cm}$ sizes. Qualitative color assessment was carried out using the Munsell standard soil color chart and the initial color was measured using a Canon MG3670 scanner and then entered into the Adobe Photoshop CS4 software which produced the values of $\mathrm{L} *$ (lightness), a* (if $-\mathrm{a}^{*}$ is a green and $+\mathrm{a}^{*}$ is a red), and $\mathrm{b} *$ (if $-b^{*}$ is a blue and $+b^{*}$ is a yellow) [8].

\section{Mordanting}

The sample cloth that has been cut with a size of $15 \times 15$ $\mathrm{cm}$ is soaked in a solution of $2 \mathrm{ml}$ of detergent in $100 \mathrm{ml}$ of distilled water to remove dirt on the cloth. The mordanting solution is made in a pan with a ratio of alum and soda ash 1: 4 in 1 liter of distilled water, then the cloth is put in the solution and then boils it to a temperature of $100^{\circ} \mathrm{C}$. Then the pan is removed and left for 24 hours then the cloth is rinsed, dried and ironed [9].

\section{Mangrove Leaf Extraction (Bruguieragymnorrhiza)}

The raw material is mangrove leaves which are extracted by heating at $100^{\circ} \mathrm{C}$ by drying the leaf samples in open air with indirect sunlight for 10 days, then the leaves are cut into small pieces with a size of $\pm 2 \mathrm{~cm}$ then the leaf pieces and water are put into a pot with a ratio of $1: 10$ which means as much as $400 \mathrm{~g}$ pieces of mangrove leaves and $4000 \mathrm{ml}$ of water, then boil it until the water is reduced to half. Filtering is carried out using filter paper to separate the remaining extracted material.

\section{Experimental Design \\ Dyeing Fabric}

The chilled extract solution was put into a bucket then cotton, rayon, and sateen cloths were soaked in the extract solution of Bruguiera gymnorrhizas leaves for 24 hours and then the cloth was removed and drained. Qualitative color assessment was carried out using the Munsell Standard soil color chart and then measured the color change with the Canon MG3670 Scanner programmed by Adobe Photoshop CS4 which later produced L*, a*, and b * [8].

\section{Fixation}

The fixation process is used to lock in the resulting dyeing. The fixators used in this study were tunjung with weight variations of $30 \mathrm{~g} / 1,60 \mathrm{~g} / 1$, and $90 \mathrm{~g}$ / 1. The fixator material is put in 3 containers, the fixator is dissolved in $1000 \mathrm{ml}$ of water and stirred is carried out until the fixator substance dissolves in water. The fixator solution was deposited for 24 hours. The fixator is filtered and the clear solution is taken. The cloth that has been dipped in the extract solution is put into the fixator solution for 15 minutes. The cloth is then washed with water and dried in the shade.

\section{Hot Water-Color Fastness Test}

The color fastness test of the fabric is carried out by boiling water with an initial temperature of $\pm 38^{\circ} \mathrm{C}$ and then placing the cotton, rayon, and sateen cloth in the pan for 1 hour under low heat. The cloths are then removed and air dried for 24 hours. Assessment of the color of cotton, rayon, and sateen fabrics after a qualitative fastness test with the Munsell Standard soil color chart and the color will be measured by Canon MG3670 Scanner on Adobe Photoshop CS4 software which will produce L *, a *, and $b *[10]$.

\section{Cold Water-Color Fastness Test}

The color fastness test on fabrics was carried out with ice cubes, which were waiting to melt in a container with an initial temperature of $4-50 \mathrm{C}$ and then soaked in cotton, rayon and sateen fabrics for 1 hour. The cloth is then parched and drained for 24 hours. Qualitative color assessment was carried out with the Munsell Standard soil color chart and the color was measured by the Canon MG3670 Scanner in Adobe Photoshop CS4 software which would produce $\mathrm{L} *$, $\mathrm{a} *$, and $\mathrm{b} *$ [10].

\section{Data Analysis}

Data analysis used descriptive qualitative analysis, quantitative and parametic ANOVA test with a significance level of $\alpha=0.05$. This study will also produce data, namely the effect of value differences based on the $\Delta \mathrm{E}$ value [5], as follows:

$$
\Delta E=\sqrt{(\Delta \mathrm{L} *)^{2}+(\Delta \mathrm{a} *)^{2}+(\Delta \mathrm{b} *)^{2}}
$$

$$
\begin{array}{ll}
\Delta \mathrm{E} & =\text { Color Difference } \\
\Delta \mathrm{L} * & =\text { Difference in brightness }=\mathrm{L} * \text { sample test } \\
& -\mathrm{L} * \text { control } \\
\Delta \mathrm{a} * & =\text { Difference in red or green }=\mathrm{a} * \text { sample } \\
& \text { test-a } * \text { control } \\
\Delta \mathrm{b} * & =\text { Difference in yellow or blue }=\mathrm{b} * \text { sample } \\
& \text { test- } \mathrm{b} * \text { control }
\end{array}
$$

Table 1. Effect of difference in $E$ value (influence of value differences of $\Delta \mathrm{E}$ )

\begin{tabular}{|l|l|}
\hline Color Difference $(\Delta \mathrm{E})$ & Influence \\
\hline$<0.2$ & Not visible \\
\hline $0.2-1.0$ & Very small \\
\hline $1.0-3.0$ & Small \\
\hline $3.0-6.0$ & Moderate \\
\hline$>6.0$ & Big \\
\hline
\end{tabular}

\section{Adobe Photoshop}

Retrieval of $\mathrm{L} * \mathrm{a} * \mathrm{~b} *$ data on cotton, rayon and viscose fabrics using the Adobe Photoshop CS4 software application which starts by scanning each cloth then first opens the software then selects menu file> open file> select menu image> mode> Lab Then the color sampler tool was selected and then selected the sample size 5 by 5 average because for averaging the final stage marks the right, left, top and bottom four points. 


\section{RESULTS AND DISCUSSIONS}

\section{Fabric fixation with mangrove leaf staining}

This study used B. gymnorrhiza leaf extract obtained from boiling with an initial volume of 4 liters consisting of water and 1: 10 leaves giving the final volume yield for the extract as much as 2 liters. The results of boiling have a higher color intensity because temperature results in an increase in the intensity of the color of the extracted with a high extraction rate. These results are in line with research conducted by [12], that the higher the extraction temperature used will produce the color intensity of the extract to be produced.

The water used uses distilled water to extract natural dyes from B.gymnorrhiza leaves. The selection of this solvent is based on its polar constituent components from tannins which are easily soluble in polar solvents. The extraction process is carried out in a neutral atmosphere, before the research, the leaves are dried in the sun for \pm 10 days. Drying serves to reduce the moisture content in the leaves which can affect the extraction process. The leaves are cut into small pieces $\pm 2 \mathrm{~cm}$ in size, this aims to help the extraction process where the diffusion of chemicals will come out of the plant matrix so that later it can produce a dark brown color. [13] says, dark brown color indicates the presence of tannin compounds from the extraction of B. gymnoorhiza leaves.

Rayon is a semi-cellulose material, while sateen is made of polyester. The dyeing of rayon and sateen shows a different color when compared to cotton. Visually, the color of sateen is more uneven than rayon and cotton. The coloring of the cotton fabric with each treatment shows a slightly different color direction for the use of fixing materials with different weights. Visually in Table 2, the color produced by $\mathrm{FeSO}_{4}$ fixation (tunjung) with a weight of 30 grams is lighter than the darker weight of 90 grams.

Table 2. Results of Staining of Textiles with Fixation

\begin{tabular}{|l|l|l|l|}
\hline & $\begin{array}{l}\text { Cotton } \\
\text { Fabric }\end{array}$ & $\begin{array}{l}\text { Rayon } \\
\text { Fabric }\end{array}$ & $\begin{array}{l}\text { Sateen } \\
\text { Fabric }\end{array}$ \\
\hline $\begin{array}{l}\text { Tunjung 30 } \\
\text { grams }\end{array}$ & & & \\
\hline $\begin{array}{l}\text { Tunjung 60 } \\
\text { grams }\end{array}$ & & & \\
\hline $\begin{array}{l}\text { Tunjung 90 } \\
\text { grams }\end{array}$ & & & \\
\hline Without & & & \\
\hline
\end{tabular}

The color of the natural coloring pigment in mangrove leaves B. gymnorrhiza has a brownish yellow color. Natural dyes when viewed on various fabrics produce color differences, this is due to the variations in the different fabrics used. The dyeing process on cotton fabrics is more evenly distributed to all parts because cotton fabrics contain cellulose fibers, this is in accordance with [14] opinion, that cellulose fibers in cotton fabrics have enough hydroxyl groups so that they have hygroscopic properties of dimalsthat make dyes absorbable well while according to[6], the difference in color is caused more by the absorption of the color of the metal used as a fixation. The $-\mathrm{OH}$ group in cellulose fiber macromolecules is responsible for reactivity.

Table 3. Standart Munsell Soil Color Chart

\begin{tabular}{|l|l|l|l|}
\hline & $\begin{array}{l}\text { Cotton } \\
\text { Fabric }\end{array}$ & $\begin{array}{l}\text { Rayon } \\
\text { Fabric }\end{array}$ & $\begin{array}{l}\text { Sateen } \\
\text { Fabric }\end{array}$ \\
\hline $\begin{array}{l}\text { Tunjung 30 } \\
\text { grams }\end{array}$ & & & \\
\hline $\begin{array}{l}\text { Tunjung 60 } \\
\text { grams }\end{array}$ & & & \\
\hline $\begin{array}{l}\text { Tunjung 90 } \\
\text { grams }\end{array}$ & & & \\
\hline Without & & & \\
\hline
\end{tabular}

The results of the staining are based on Table $\mathbf{3}$, the coloring of mangrove leaves (B.gymnorrhiza) with different tunjung weights, namely 30 grams, 60 grams, and 90 grams on the color observation results with cotton, rayon, and sateen fabrics, it was found that there were different color changes.The color measurement results were measured by Munsell soil color chart as a color guideline, there was a change in the cotton cloth without fixation, namely Light Yellow Orange 10YR 8/3, after staining with $30 \mathrm{gr}$ tunjung fixation it changed to Grayish Yellow 2.5 Y $6 / 2$ then with The 60 gr stand changes to Light Brownish Gray 7.5 YR 7/1 and with the 90 gr stand the same color Light Brownish Gray 7.5 YR 7/1. Before

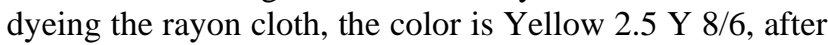
dyeing with $30 \mathrm{gr}$ tunjung fixation changes its color to Light Brownish Gray 7.5 YR 7/2, staining with $60 \mathrm{gr}$ tunjung fixation resulted in Dull Yellow Orange 10YR 7/2 color, and with $90 \mathrm{~g}$ tunjung fixation, Light Gray $10 \mathrm{YR}$ $8 / 1$ coloration. The color of the sateen fabric before dyeing is Light Yellow Orang 10 YR 8/3, after dyeing it with 30 gr tunjung fixation, Light Gray 10 YR 7/1, 60 gram tunjung fixation, Light Gray 10 YR 8/1 sateen fabric then with tunjung 90 fixation gr color sateen fabric Dull Yellow Orange $10 \mathrm{YR} 7 / 2$. The difference in the color of the resulting fabric is influenced by the amount of natural dye (tannin) content. produced from mangrove leaves B.gymnorrhiza and the presence of a fixator that will affect the quality of the fabric color produced. The addition of metal in the fixation process can increase the complexity between the fiber molecule and the dye molecule so that the color intensity that will be produced is stronger than the treatment without fixation, this is in accordance with [17], namely the change of iron sulfate into ferric sulfate form which will react with oxygen in the air. darkens the fabric.

The $\mathrm{L} * \mathrm{a} * \mathrm{~b} *$ color coordinate values for the colors of cotton, rayon, and sateen fabrics with mangrove leaf dye are shown in Table 4. 
Table 4. Coordinate Value of $\left(\mathrm{L}^{*}\right)\left(\mathrm{a}^{*}\right)\left(\mathrm{b}^{*}\right)$ Fabric Color with Natural Dyes

\begin{tabular}{|c|c|c|c|c|c|}
\hline$*$ & $\mathbf{L} *$ & $\mathbf{a} *$ & b* & $\Delta E$ & Mean \\
\hline Ka1 & 63.75 & 5.25 & 8.75 & 29.77 & \multirow[t]{2}{*}{29,275} \\
\hline Ka2 & 65 & 5.25 & 9 & 28.78 & \\
\hline Kb1 & 63 & 4.75 & 9.25 & 31.04 & \multirow[t]{2}{*}{30,095} \\
\hline $\mathrm{Kb2}$ & 64.5 & 6.25 & 8.5 & 29.15 & \\
\hline Kc1 & 62 & 5.75 & 10 & 31.98 & \multirow[t]{2}{*}{30.57} \\
\hline Kc2 & 64.25 & 4.25 & 8.75 & 29.16 & \\
\hline Ra1 & 65 & 5 & 10.75 & 29.71 & \multirow[t]{2}{*}{24.69} \\
\hline Ra2 & 74 & 5.25 & 10.75 & 19.67 & \\
\hline Rb1 & 64.5 & 5 & 9.75 & 29.87 & \multirow{2}{*}{26,255} \\
\hline $\mathrm{Rb2}$ & 72.25 & 5.75 & 9.5 & 22.64 & \\
\hline Re1 & 63.25 & 5.5 & 10.5 & 31.28 & \multirow[t]{2}{*}{27.2} \\
\hline Rc2 & 72 & 6 & 9.75 & 23.12 & \\
\hline Sa1 & 74.75 & 3.25 & 7 & 17.17 & \multirow[t]{2}{*}{14,935} \\
\hline Sa2 & 76 & 4.5 & 7.5 & 12.70 & \\
\hline Sb1 & 74 & 5.75 & 4 & 16.77 & \multirow[t]{2}{*}{14.96} \\
\hline Sb2 & 73.75 & 4.5 & 7.5 & 13.15 & \\
\hline Sc1 & 68 & 4.75 & 9.25 & 24.22 & \multirow[t]{2}{*}{19,425} \\
\hline Sc2 & 71.25 & 2.5 & 7.5 & 14.63 & \\
\hline
\end{tabular}

Tabel 5. Information for Symbols

\begin{tabular}{|l|l|}
\hline $\mathrm{Ka} 1$ & experimental cotton 130 grams \\
\hline $\mathrm{Ka} 2$ & experimental cotton 230 grams \\
\hline $\mathrm{Kb} 1$ & experimental cotton 160 grams \\
\hline $\mathrm{Kb} 2$ & experimental cotton 260 grams \\
\hline $\mathrm{Kc} 1$ & experimental cotton 190 grams \\
\hline $\mathrm{Kc} 2$ & experimental cotton 290 grams \\
\hline $\mathrm{Ra} 1$ & experimental rayon 130 grams \\
\hline $\mathrm{Ra} 2$ & experimental rayon 230 grams \\
\hline $\mathrm{Rb} 1$ & experimental rayon 160 grams \\
\hline $\mathrm{Rb} 2$ & experimental rayon 260 grams \\
\hline $\mathrm{Rc} 1$ & experimental rayon 190 grams \\
\hline $\mathrm{Rc} 2$ & experimental rayon 290 grams \\
\hline $\mathrm{Sa} 1$ & experimental sateen 130 grams \\
\hline $\mathrm{Sa} 2$ & experimental sateen 230 grams \\
\hline $\mathrm{Sb} 1$ & experimental sateen 160 grams \\
\hline $\mathrm{Sb} 2$ & experimental sateen 260 grams \\
\hline $\mathrm{Sc} 1$ & experimental sateen 190 grams \\
\hline $\mathrm{Sc} 2$ & experimental sateen 290 grams \\
\hline
\end{tabular}

Color changes in cotton, rayon, and satin fabrics were measured based on the $\Delta \mathrm{E}$ value obtained from the color assessment before and after dyeing. Color change occurs when $\Delta \mathrm{E}$ value $>0.2$. The value of $\Delta \mathrm{E}$ can be affected by a decrease in the value of $\mathrm{L} *$ and an increase in the values of $a *$ and $b *$. The brightness $(\mathrm{L} *)$ value of sateen in weight is higher when compared to cotton and rayon fabrics. The $\mathrm{L} *$ value of sateen fabrics ranges from 68-76 while rayon fabrics range from 63.25-74, while cotton fabrics provide a lower brightness level of $\mathrm{L} *$ than rayon fabrics, which ranges from 62-65 which means they give a darker color. Determination of the best treatment is based on the value of color difference $(\Delta \mathrm{E})$ using a tunjung fixator if the average cotton cloth has the highest absorption and value while the tunjung treatment $\left(\mathrm{FeSO}_{4}\right)$ is good for all fabrics, namely 90 grams. Cotton fabrics contain $94 \%$ cellulose fibers which tend to be easier to enter dyes because the morphology of cotton fabrics when viewed with a microscope has a longitudinal cross-section such as threads twisted into ribbons and crosswise like kidneys with a hole in the middle to facilitate absorption of natural dyes with cotton fabric fibers [14].

\section{Color fastness resistance to hot water}

The color fastness test for natural dyes that have been fixed in this study uses the ASTM D 870-02-2002 standard (hot water test). The color change in this test can be seen using the Munsell soil color chart, while qualitatively it can be seen from CIELab. Based on the results of the cloth color fastness test visually using Munsell soil color chart in hot water, the colors of some fabrics experienced major changes.

The results obtained on the fastness test on cotton cloth using hot water can be seen in Table 5, the color of the cotton cloth fades to brighter or brighter. gram colored with a tapered weight of 30 grams, the color is Grayish Yellow 2.5 Y 6/2 then with a 60 gr light brownish gray 7.5 YR 7/1 and a $90 \mathrm{~g}$ tall color is Light Brownish Gray 7.5 YR 7/1 after being tested the color becomes Dull Yellow Orange 10YR 7 / 4 on a 30 gram gazebo, a 60 gram gazebo is the color of Dull Orange 7.5YR 7/3 and a 90 gram gazebo is Pale Yellow 2.5Y 8/3.

Table 6. Results of Hot Water Color Fastness of Cotton Fabric

\begin{tabular}{|c|l|l|}
\hline & $\begin{array}{l}\text { Before the Fade } \\
\text { Test }\end{array}$ & $\begin{array}{l}\text { After the Fade } \\
\text { Test }\end{array}$ \\
\hline $\mathrm{Ka} 1$ & & \\
\hline $\mathrm{Kb} 1$ & & \\
\hline $\mathrm{Kc} 1$ & & \\
\hline
\end{tabular}

Table 7. Coordinate value of $\left(\mathrm{L}^{*}\right)\left(\mathrm{a}^{*}\right)\left(\mathrm{b}^{*}\right)$ hot water color fastness of cotton fabric

\begin{tabular}{|l|l|l|l|l|l|l|l|}
\hline & \multicolumn{3}{|l|}{ Before Testing } & \multicolumn{3}{l|}{ After Testing } & \multirow{2}{*}{$\Delta \mathrm{E}$} \\
\cline { 2 - 7 } & $\mathrm{L} *$ & $\mathrm{a} *$ & $\mathrm{~b} *$ & $\mathrm{~L} *$ & $\mathrm{a} *$ & $\mathrm{~b}$ & \\
\hline Ka1 & 63.7 & 5.2 & 8.7 & 68.2 & 6.2 & 12.5 & 5.9 \\
& 5 & 5 & 5 & 5 & 5 & & 4 \\
\hline Kb1 & 63 & 4.7 & 9.2 & 67 & 8 & 10.2 & 5.2 \\
& & 5 & 5 & & & 5 & 8 \\
\hline Kc1 & 62 & 5.7 & 10 & 66 & 7 & 13 & 5.1 \\
& & 5 & & & & & \\
\hline
\end{tabular}

The change in $\Delta \mathrm{E}$ value shows the amount of color fading value. The higher the $\Delta \mathrm{E}$ value, the greater the fidelity, conversely, the lower the $\Delta \mathrm{E}$ value, the smaller the fidelity. The effect of differences in $\Delta \mathrm{E}$ values on cotton fabrics by conducting a color fastness test against hot water has a value range between 5.1-5.94 according to [11], this value is included in the moderate category. Based on the analysis of the variety of hot water fading test with various fixators on different fabrics, significantly affected the fading rate $(\Delta \mathrm{E})$ of the extract of B.gymnorrhizaleaf pigment. The test results of the quality of the coloring show the medium fading category because 
it uses a tunjung fixator which is able to bind the dye to the cotton fabric firmly. According to [13], the strength and weakness of the bonds that occur between the fabric fibers and the dye determines the color fastness properties that are retained in the fabric fibers which will strengthen the color fastness. The color fastness process of cotton fabric at 30 grams of fixation is better than 60 gram and 90 gram fixators because the dye is more adsorbed to be bound by the $\mathrm{OH}$ group in the cellulose fiber, this bond causes the dye to melt a little, this is according to [15], that hydrogen bonds are formed between cellulose and dyes. which causes the dye difficult to get out of the fiber.

Fastness resistance to rayon fabric of B.gymnorrhizaleaves at various tunjung weights before and after the fastness test experienced a color difference which based on the color change test using Munsell soil color chart before rayon cloth was tested for hot water fastness with 30 gram weight variations Light Brownish Gray 7.5 YR 7/2, tunjung 60 gr Dull Yellow Orange 10YR $7 / 2$, and tunjung 90 gr Light Gray 10 YR 8/1 after testing hot water the color becomes Pale Yellow 2.5Y 8/4 on 30 grams, with 60 grams becomes Light Gray 7.5YR 8/2 and 90 grams remains Light Gray 7.5YR 8/2.

Table 8. Results of rayon fabric hot water color fastness resistance

\begin{tabular}{|c|l|l|}
\hline & $\begin{array}{l}\text { Before the } \\
\text { Fade Test }\end{array}$ & $\begin{array}{l}\text { After the Fade } \\
\text { Test }\end{array}$ \\
\hline Ra1 & & \\
\hline Rb1 & & \\
\hline Rc1 & & \\
\hline
\end{tabular}

Table 9. $\left(\mathrm{L}^{*}\right)\left(\mathrm{a}^{*}\right)\left(\mathrm{b}^{*}\right)$ coordinate value of rayon fabric hot water color fastness resistance

\begin{tabular}{|r|l|l|l|l|l|l|l|}
\hline \multirow{2}{*}{$*$} & \multicolumn{3}{|c|}{ Before Testing } & \multicolumn{3}{c|}{ After Testing } & \multirow{2}{*}{$\Delta \mathrm{E}$} \\
\cline { 2 - 7 } & $\mathrm{L}^{*}$ & $\mathrm{a}^{*}$ & $\mathrm{~b}^{*}$ & $\mathrm{~L}^{*}$ & $\mathrm{a}^{*}$ & $\mathrm{~b}^{*}$ & \\
\hline Ra1 & 65 & 5 & 10.75 & 72 & 5.25 & 16.5 & 9.06 \\
\hline Rb1 & 64.5 & 5 & 9.75 & 69 & 8.25 & 11.75 & 5,9 \\
\hline Rc1 & 63.25 & 5.5 & 10.5 & 68 & 5 & 15 & 6.56 \\
\hline
\end{tabular}

The change in $\Delta \mathrm{E}$ value shows the amount of color fading value. The higher the $\Delta \mathrm{E}$ value, the greater the fidelity, conversely, the lower the $\Delta \mathrm{E}$ value, the smaller the fidelity. The color change $(\Delta \mathrm{E})$ in rayon cloth has a value range of 5.56-9.06 where according to [11], this value is included in the medium (3.0-6.0) to large (> 6.0) category. rayon has the best fastness test value against hot water with low dissolution value $(\Delta \mathrm{E})$ at a fixator weight of 60 grams. At the weight of 30 grams the dye and tunjung absorbed by the rayon cloth is not optimal so that if it is increased to 60 grams, the dyestuff and the tunjung in the rayon cloth have experienced balance, so that the added weight of 90 grams does not affect the absorption of the fabric.

The results of the sateen fabric fastness test with B.gymnorrhizaleaf color against hot water are presented in
Table 4.7. fastness resistance to the sateen fabric of B.gymnorrhizaleaves at various tunjung weights before and after the fastness test experienced a color difference which based on the qualitative test using Munsell soil color chart before sateen fabric was tested for hot water fastness with variations in weight of 30 grams of light gray 10 YR 7/1, fixation of 60 grams of light graycolor 10 YR $8 / 1$ then fixation of up to 90 grams of color Dull Yellow Orange 10 YR 7/2 after testing the color to Light Gray $5 Y R 8 / 1$ on a 30 gram stand, with a stand of 60 grams the color is Light Brownish Gray 5YR 7/2 and up to 90 grams, the color is still Light Gray 7.5YR 8/1.

Table 10. Results of the hot water color fastness of sateen fabric

\begin{tabular}{|l|l|l|}
\hline$*$ & $\begin{array}{l}\text { Before the Fade } \\
\text { Test }\end{array}$ & $\begin{array}{l}\text { After the Fade } \\
\text { Test }\end{array}$ \\
\hline Sa1 & & \\
\hline Sb1 & & \\
\hline Sc1 & & \\
& & \\
\hline
\end{tabular}

Table 11. Coordinate value of $\left(\mathrm{L}^{*}\right)\left(\mathrm{a}^{*}\right)\left(\mathrm{b}^{*}\right)$ hot water color fastness of sateen fabric

\begin{tabular}{|l|l|l|l|l|l|l|l|}
\hline$*$ & \multicolumn{3}{|c|}{ Before Testing } & \multicolumn{3}{|c|}{ After Testing } & \multirow{2}{*}{$\Delta \mathrm{E}$} \\
\cline { 2 - 7 } & $\mathrm{L}^{*}$ & $\mathrm{a}^{*}$ & $\mathrm{~b}^{*}$ & $\mathrm{~L} *$ & $\mathrm{a}^{*}$ & $\mathrm{~b}^{*}$ & \\
\hline Sa1 & 74.75 & 3.25 & 7 & 75.5 & 4 & 10.5 & 3.65 \\
\hline Sb1 & 74 & 5.75 & 4 & 75 & 8.75 & 6 & 3.74 \\
\hline Sc1 & 68 & 4.75 & 9.25 & 69 & 7.75 & 12.25 & 4.35 \\
\hline
\end{tabular}

The dyeing process on the sateen fabric results is uneven in each part due to the slippery nature of the fabric and is made of polyester so that the dye is less absorbed into the fabric, but if the results of the fabric color fastness test only fade slightly, the fading of the fabric is a little helped by the substance. fixed fixator. Color change $(\Delta \mathrm{E})$ in sateen has a value range of 3.65-4.35, which according to [11], is in the moderate category (3.0-6.0).

\section{Color fastness resistance to cold water}

Color fastness is an element that largely determines the quality of a dye material. The color fastness test of natural dyes that have been fixed in this study uses the ASTM D 1308-02-2013 standard (cold water test). The color change in the fading test qualitatively can be seen using the Munsell soil color chart, while qualitatively the magnitude of the color fading of the cloth immersion in cold water can be seen the CIELab value.

The cotton cloth fixed with 30 gr tunjung $2.5 \mathrm{Y}$ $6 / 2$ grayish yellow then 60 gr tunjung 7.5 YR 7/1 and 90 gr tunjung the same color Light Brownish Gray 7.5 YR $7 / 1$ after testing cold water color fastness There is a slight change in color, namely with a $30 \mathrm{~g}$ gazebo in Grayish 
Yellow 2.5Y 7/2 with a $60 \mathrm{~g}$ gazebo in Light Brownish Gray 7.5YR 7/2 and a 90 gr tunjung 7.5YR 7/3 Dull Orange. Cotton fabric has good color fastness resistance to cold water for all types of weight on the fixed fixator, this indicates a very strong bond between B.gymnorrhiza leaf dye and the three weight of the staves in the coloring process. The fixation process increases the interaction between the dye and the fiber by forming a complex that results in higher absorption of the dye and the stability of the dye. This condition causes the dye released when in cold water is very small.

Table 12. Cold water color fastness resistance results cotton fabric

\begin{tabular}{|l|l|c|}
\hline$*$ & $\begin{array}{c}\text { Before the } \\
\text { Fade Test }\end{array}$ & $\begin{array}{c}\text { After the Fade } \\
\text { Test }\end{array}$ \\
\hline Ka2 & & \\
\hline Kb2 & & \\
\hline Kc2 & & \\
\hline
\end{tabular}

Table 3. Coordinate values of $\left(\mathrm{L}^{*}\right)\left(\mathrm{a}^{*}\right)\left(\mathrm{b}^{*}\right)$ cold water color fastness of cotton fabric

\begin{tabular}{|l|l|l|l|l|l|l|l|}
\hline \multirow{2}{*}{$*$} & \multicolumn{3}{|l|}{ Before Testing } & \multicolumn{3}{c|}{ After Testing } & \multirow{2}{*}{$\Delta \mathrm{E}$} \\
\cline { 2 - 7 } & $\mathrm{L}^{*}$ & $\mathrm{a}^{*}$ & $\mathrm{~b}^{*}$ & $\mathrm{~L}^{*}$ & $\mathrm{a}^{*}$ & $\mathrm{~b}^{*}$ & \\
\hline $\mathrm{Ka} 2$ & 65 & 5.25 & 9 & 64.25 & 6 & 10.75 & 2.04 \\
\hline $\mathrm{Kb} 2$ & 64.5 & 6.25 & 8.5 & 66 & 5 & 8.25 & 1.96 \\
\hline $\mathrm{Kc} 2$ & 64.25 & 4.25 & 8.75 & 66.25 & 7.25 & 9.5 & 3.68 \\
\hline
\end{tabular}

The change in $\Delta \mathrm{E}$ value shows the amount of color fading value. The higher the $\Delta \mathrm{E}$ value, the greater the fidelity, conversely, the lower the $\Delta \mathrm{E}$ value, the smaller the fidelity. The effect of the difference in the value of $\Delta \mathrm{E}$ on cotton cloth with a color fading test for cold water has a value range between 1.96-3.68 according to[11], this value is included in the small (1.0-3.0) and medium (3.0-6.0). These results indicate that the weight factor has a significant effect on color fastness due to cold water. The higher the weight of the B.gymnorrhizasolution, the fastness value tends to decrease. This situation is caused by the absorption of dye molecules into the cellulose fibers, most of which are an imbibition process [16]. The imbibition process is the process of moving dye molecules from a high-weight to a low-weight solution, namely from the dye solution to the fiber, the greater the weight of the dye in the mangrove leaf, the higher the dye weight in the fabric fiber, until a balance occurs. The increase in the weight of the fixed fixator causes the dye to stick to the surface fibers because the weight of the dye in the fabric fibers is saturated, resulting in a decreased color fastness value.

Based on the results of the visual fading of the fabric color using Munsell soil color chart in cold water, the color of the rayon cloth has changed slightly. Tunjung fixation of $30 \mathrm{gr}$ in Light Brownish Gray 7.5 YR 7/2, tunjung fixation of $60 \mathrm{gr}$ in Dull Yellow Orange 10YR 7/2, and tunjung fixation of $90 \mathrm{gr}$ in Light Gray $10 \mathrm{YR}$ 8/1 after being tested for fastness to cold water, rayon cloth which is fixed with a $30 \mathrm{gr}$ stand to be Light Gray 7.5YR $8 / 2$, with a 60 gr stand in Dull Yellow Orange 10YR 7/3 and a 90 gr tunjung 10 YR 8/2 Light Gray.

Color change $(\Delta \mathrm{E})$ in rayon cloth has a range of values from 2.83 to 3.9 , which according to [11], is in the small category (1.0-3.0). The value of color fastness to cold water using the weight variance of the fixed fixator on rayon cloth can affect the fading rate. It can be seen that with a 60 gram tunjung fixator the $\Delta \mathrm{E}$ value changes to 2.83. The fixation process increases the interaction between the dye and the fiber by forming a complex that results in higher absorption of the dye and the stability of the dye. This condition causes the dye released when in cold water is very small

Table 14. Cold water color fastness results of rayon fabric

\begin{tabular}{|l|l|l|}
\hline$*$ & $\begin{array}{l}\text { Before the } \\
\text { Fade Test }\end{array}$ & $\begin{array}{l}\text { After the } \\
\text { Fade Test }\end{array}$ \\
\hline $\mathrm{Ra} 2$ & & \\
\hline $\mathrm{Rb} 2$ & & \\
\hline $\mathrm{Rc} 2$ & & \\
\hline
\end{tabular}

Table 15. Coordinate values of $\left(\mathrm{L}^{*}\right)\left(\mathrm{a}^{*}\right)\left(\mathrm{b}^{*}\right)$ cold water color fastness of rayon fabric

\begin{tabular}{|r|l|l|l|l|l|l|l|}
\hline$*$ & \multicolumn{3}{|l|}{ Before Testing } & \multicolumn{3}{|c|}{ After Testing } & \multirow{2}{*}{$\Delta \mathrm{E}$} \\
\cline { 2 - 7 } & $\mathrm{L} *$ & $\mathrm{a} *$ & $\mathrm{~b} *$ & $\mathrm{~L} *$ & $\mathrm{a} *$ & $\mathrm{~b} *$ & \\
\hline $\mathrm{Ra} 2$ & 74 & 5.25 & 10.75 & 74.25 & 5.5 & 12.75 & 2.03 \\
\hline $\mathrm{Rb} 2$ & 72.25 & 5.75 & 9.5 & 72.5 & 5.25 & 12.25 & 2.83 \\
\hline $\mathrm{Rc} 2$ & 72 & 6 & 9.75 & 73 & 5.5 & 12.25 & 2.7 \\
\hline
\end{tabular}

Based on the results of the visual fading of the fabric color using Munsell soil color chart in cold water, the color of the sateen fabric has changed slightly. Fixation of 30 grams of light Gray 10 YR 7/1, fixation of tunjung 60 grams of color of sateen fabric Light Gray 10 YR 8/1 then fixation of 90 grams of sateen fabric color of Dull Yellow Orange 10 YR 7/2 after being tested for color fastness to Cold water has changed colors, 30 grams of light gray 10YR 8/1, 60 grams of light Gray 10YR 8/1 and 90 grams of color Dull Orange 7.5YR 7/3.

Table 16. Results of cold water color fastness of sateen fabric

\begin{tabular}{|l|l|l|}
\hline$*$ & $\begin{array}{l}\text { Before the } \\
\text { Fade Test }\end{array}$ & $\begin{array}{l}\text { After the } \\
\text { Fade Test }\end{array}$ \\
\hline $\mathrm{Sa} 2$ & & \\
\hline $\mathrm{Sb} 2$ & & \\
\hline $\mathrm{Sc} 2$ & & \\
\end{tabular}


Table 17. Coordinate values of $\left(\mathrm{L}^{*}\right)\left(\mathrm{a}^{*}\right)\left(\mathrm{b}^{*}\right)$ cold water color fastness of sateen fabric

\begin{tabular}{|r|l|l|l|l|l|l|l|}
\hline$*$ & \multicolumn{5}{|c|}{} & \multicolumn{3}{|l|}{} & \multirow{2}{*}{$\Delta \mathrm{E}$} \\
& \multicolumn{3}{|l|}{ Before Testing } & \multicolumn{3}{|l|}{ After Testing } & \\
\cline { 2 - 7 } & $\mathrm{L}^{*}$ & $\mathrm{a} *$ & $\mathrm{~b}^{*}$ & $\mathrm{~L} *$ & $\mathrm{a} *$ & $\mathrm{~b} *$ & \\
\hline $\mathrm{Sa} 2$ & 76 & 4.5 & 7.5 & 76.75 & 5 & 8.75 & 1.54 \\
\hline $\mathrm{Sb} 2$ & 73.75 & 4.5 & 7.5 & 74.25 & 5.25 & 5.5 & 2.29 \\
\hline
\end{tabular}

\section{CONCLUSIONS}

The addition of $\mathrm{FeSO}_{4}$ fixing agent gives a different color to each type of fabricbut it caused darker. The (L*) value of sateen fabrics ranges from 68-76 while rayon fabrics range from $63.25-74$, while cotton fabrics provide a lower brightness level of $\left(\mathrm{L}^{*}\right)$ than rayon fabrics, which ranges from 62-65 which means they give a darker color. Determination of the best treatment is based on the value of color difference $(\Delta \mathrm{E})$ using a tunjung fixator if the average cotton cloth has the highest absorption and value while the tunjung treatment $\left(\mathrm{FeSO}_{4}\right)$ is good for all fabrics,

\section{REFERENCES}

[1] Anggraini Cahyani, M. D., \& Novidayasa, I. (2016). Ekstraksi Zat Warna Alam Dari Kayu Bakau (Rhizopora mucronata) Dengan Metode Microwave Assisted Extraction. Surabaya: Jurusan Teknik Kimia, ITS.

[2] Purwanto. (2018). Hasil Uji Beda Warna Bahan Alami Sebagai Salah Satu Alternatif Pewarnaan pada Bahan Kain Batik. Jurnal Itenas Rekarupa ,54-61.

[3] Paryanto, Wibowo, W. A., \& Aditya, M. H. (2016). Pembuatan Zat Warna Alami Dari Buah Mangrove Spesies Rhizopora stylosa Sebagai Pewarna Batik Ramah Lingkungan Dalam Skala Pilot Plan. Prosiding Seminar Nasional Teknologi Pengelolaan Limbah XIV (hal. 76-81). Batan: Pusat Teknologi Limbah Radioaktif.

[4] Schofield, Mbuagua, D., \& Pell. (2001). Analysis of Condensed Tannins. Animal Feed Science and Technology , 21-40.

[5] Anggraini, R. R., Hendri, M., \& Rozirwan. (2018). Potensi Larutan Bubuk Daun Mangrove Bruguiera gymnorrhiza Sebagai Pengawet Alami. Maspari Journal , 51-62.

[6] Failisnur, Sofyan, \& Hermianti, W. (2017). Pemanfaatan Limbah Cair Pengempaan Gambir Untuk Pewarnaan Kain Batik. Jurnal Litbang Industri , 19-28.

[7] Kurniawati, E., \& Yulistiana. (2015). Batik Mangrove Rungkut Surabaya. e-Journal , 37-45.

[8] Septiandini, T. N., \& Muflihati. (2019). Ekstrak Buah Bakau Rhizopora mucronata Lamk Sebagai Pewarna Alami Pada Kain Katun. Jurnal Tengkawang, 1-13.

[9] Fona, Z., \& Syafruddin. (2016). Pengujian Ketahanan Luntur Terhadap Pencucian Dan Gosokan Tekstil Hasil Pewarnaan Dengan Ekstrak Curcumin Induk Kunyit. Seminar Nasional Inovasi IPTEKS Perguruan Tinggi

\begin{tabular}{|l|l|l|l|l|l|l|l|}
\hline Sc2 & 71.25 & 2.5 & 7.5 & 72 & 2.75 & 9.5 & 2.76 \\
\hline
\end{tabular}

Color change $(\Delta \mathrm{E})$ in sateen has a value range of 1.54-2.76, which according to [11], is in the small category (1.0-3.0), it is assumed that the nature of cotton cloth is less absorbent a fixator so that when the fabric dyeing process, a lot of it has faded so when tested for fastness the value of $\Delta \mathrm{E}$ is small.

namely 90 grams. The results of the color fastness value in hot water are influenced by the difference in $\Delta \mathrm{E}$ (color fastness), cotton fabrics have a range of values between the medium category (5.1-5.94), the medium-large category rayon cloth (5.09-9.06), medium category sateen (3.65-4.35).The results of the color fastness value in cold water are influenced by the difference in $\Delta \mathrm{E}$ (color fastness), cotton fabrics have a range of values between small and medium categories (1.96-3.68), rayon fabrics in the small category (2.83-3.9), the small category of sateen fabrics (1.54-2.76).

Untuk Meningkatkan Kesejahteraan Masyarakat. Bali: LPPM UNMAS Denpasar.

[10] Muflihati, Nawawi, D., Rahayu, I., \& Syafii, W. (2014). Perubahan Warna Kayu Jabon Terwarnai Ekstrak Kulit Kayu Samak (Syzygium inophyllum). Jurnal Ilmu dan Teknologi Kayu Tropis , 11-19.

[11] H. L. (2008). Hunter Lab Color. Dipetik July Sabtu, 2020, dari www.hunterlab.com

[12] Mulyanto, S., Suyitno, Rachmanto, R., \& Hidayat. (2016). Synthesis and characterization of natural red dye from Caesalpinia sappan linn. AIP Conf. Proc , 1-7

[13] Widowati, T.B. dan G. Sutapa. 2012. Pemanfaatan Bagian Cabang dan Pucuk Cabang Dalbergia latifolia sebagai Pewarna Alami Kain Batik. Dalam: Prosiding Seminar Nasional Masyarakat Peneliti Kayu Indonesia (MAPEKI) XVI di Makassar Tanggal 6-7 November 2012.

[14] Noerati et al. 2013. Bahan Ajar Pendidikan dan Latihan Profesi Guru (PLPG) Teknologi Tekstil. Yogyakarta : Sekolah Tinggi Tekstil.

[15] Rosyida, A., \& Zulfiya, A. (2013). Pewarnaan bahan tekstil dengan menggunakan ekstrak kayu nangka dan teknik pewarnaannya untuk mendapatkan hasil yang optimal. Jurnal Rekayasa Proses, 7(2), 51 \pm 57 .

[16] Lukas, A. (2011). The Use Of Gambir As Coloring Agent In Dyeing Of Cotton Textile. Jurnal Dinamika Penelitian Industri , 19-27. 